\title{
Frequent coconut milk intake increases the risk of vascular disease in adults
}

\author{
Sulistyowati Tuminah*, and Marice Sihombing**
}

\section{ABSTRACT}

\section{BACKGROUND}

Coconut milk is an essential ingredient of the Indonesian cuisine. In view of its saturated fatty acid content, coconut milk has frequently been blamed as a cause of cardiovascular disease. The objective of this study was to determine any association between coconut milk intake and vascular disease among adults.

\section{METHODS}

A cross-sectional study was conducted in 2011-2012 on adults aged 2565 years. Self-reported health and nutritional data were collected by means of questionnaire-based interviews, with the aid of 3-D food models. Medical data comprised blood pressure and anthropometry (waist circumference and body mass index), neurological status, ECG, blood glucose and lipid profile. Data analysis was done using multiple logistic regression.

\section{RESULTS}

A total of 4,187 respondents fullfilled the inclusion criteria. Frequent coconut milk intake ( $\geq 3$ times/week) significantly increased the risk of vascular disease by 1.3-fold compared with infrequent coconut milk intake ( $\leq 2$ times/week) $(\mathrm{OR}=1.33$; 95\% CI: 1.11-1.60; $\mathrm{p}=0.002)$ after controlling for age, gender, hypertension, diabetes mellitus and stress. The influence of coconut milk intake on vascular disease risk was lower than that of age, gender, hypertension and diabetes mellitus.

\section{CONCLUSION}

Frequent coconut milk intake increased the risk of vascular disease in adults. Further investigations are needed about the effect of coconut milk intake on noncommunicable diseases.
*Center for Community Health Intervention Technology, Health Research and Development Board, Ministry of Health, Republic of Indonesia **Center for Clinical Epidemiology and Applied Health Technology, Health Research and Development Board, Ministry of Health, Republic of Indonesia

\section{Correspondence:}

Sulistyowati Tuminah, S.Si Center for Community Health Intervention Technology, Health Research and Development Board, Ministry of Health, Republic of Indonesia Jl. Percetakan Negara No. 29,

Jakarta Pusat

E-mail :

sulistyowati@litbang.depkes.go.id/ sdarjoko@yahoo.com

Univ Med 2015;34:149-58

DOI: 10.18051/UnivMed.2016.v35.149-158 pISSN: 1907-3062 / eISSN: 2407-2230

This open access article is distributed under a Creative Commons Attribution-Non Commercial-Share Alike 4.0 International License

Keywords: Coconut milk intake, vascular disease, adult 


\section{Asupan santan yang sering meningkatkan risiko terjadinya penyakit vaskuler pada orang dewasa}

\section{ABSTRAK}

\section{LATAR BELAKANG}

Santan merupakan salah satu bahan dalam masakan Indonesia. Di sisi lain, santan yang merupakan produk kelapa yang sering dianggap sebagai penyebab penyakit pembuluh darah vaskuler karena banyak mengandung asam lemak jenuh. Tujuan penelitian ini adalah untuk menentukan hubungan antara asupan santan dengan penyakit vaskuler $(P V)$ [stroke atau penyakit jantung koroner/PJK] pada orang dewasa.

\section{METODE}

Rancangan penelitian yang digunakan adalah rancangan potong lintang (cross sectional) yang dilaksanakan antara bulan Januari 2011 sampai Desember 2012 pada responden yang berusia 25-65 tahun. Pengumpulan data dilakukan dengan cara: 1). wawancara tentang kesehatan masyarakat menggunakan kuesioner dan wawancara gizi menggunakan kuesioner serta food model, 2). pemeriksaan kesehatan yang meliputi: a). pengukuran tekanan darah dan antropometri (lingkar perut, berat dan tinggi badan), b). pemeriksaan nerologi dan rekam jantung $(E K G), c)$. pemeriksaan darah laboratorium (kadar glukosa darah puasa dan 2 jam post prandial, kolesterol total, $H D L, L D L$ dan trigliserida). Regresi logistik ganda digunakan untuk analisis data.

\section{HASIL}

Data yang memenuhi kriteria inklusi sebanyak 4.187 responden. Asupan santan yang sering ( $\geq 3 \mathrm{kali} / \mathrm{minggu})$ meningkatkan risiko untuk mengalami penyakit vaskuler secara bermakna sebesar 1,3 kali $($ OR=1,33; 95\% CI: 1,11-1,60; $p=0,002)$ dibandingkan dengan asupan yang jarang ( $\leq 2 \mathrm{kali/minggu})$ setelah dikontrol oleh umur, jenis kelamin, hipertensi, diabetes dan stres. Namun besaran risikonya terhadap penyakit vaskuler tersebut masih lebih kecil dibandingkan dengan faktor umur, jenis kelamin, hipertensi dan diabetes.

\section{KESIMPULAN}

Asupan santan yang sering meningkatkan risiko mengalami penyakit vaskuler pada orang dewasa. Penelitian lebih lanjut mengenai asupan santan terhadap penyakit tidak menular masih sangat diperlukan.

Kata kunci: Asupan santan, penyakit vaskuler, dewasa

\section{INTRODUCTION}

Coconuts have a high content of saturated fatty acids, which is the reason why coconuts and coconut products are frequently categorized as "bad fat" and a cause of heart disease. This is in spite of the fact that the majority of the saturated fatty acids are medium chain fatty acids $(\mathrm{C} 8-\mathrm{C} 12)$ with features and metabolism that are different from those of saturated fatty acids of animal origin. Medium chain saturated fatty acids in coconuts are not enzymatically hydrolyzed, but can be directly absorbed by the intestinal wall and carried in the circulation to be metabolized in the liver. In the liver, these medium chain fatty acids are converted into energy only and not into cholesterol or adipose tissue. ${ }^{(1)}$

The fatty acid composition of coconut oil has been determined, but only little is known about other coconut products, such as coconut milk, coconut water, coconut cream, and grated coconut meat. Coconut water has a low fat content, coconut milk contains $24 \%$ fat, whereas coconut cream and grated coconut meat have a fat content of approximately 34\%.(2) Coconut milk is a product made from coconut meat (endosperm) by 
pressing grated coconut meat with water. It has a milky color, being an emulsion of water, protein and oil. The fat content of coconut milk is around $17 \%$, approximately $90-92 \%$ of which is saturated. Although coconut milk fat is more saturated than most oils and fats, around $2 / 3$ of the saturated fatty acids are medium chain fatty acids. An experimental study by Ejike et al. ${ }^{(3)}$ showed that coconut milk did not increase the risk of cardiovascular disease in consumers of coconut milk as food or medication.

A case-control study on coronary heart disease (CHD) was conducted in the Minangkabau community, known for its high coconut consumption. In this study, the controls and cases received a total saturated fatty acid intake of 27 grams/day, equivalent to 129 grams of coconut milk or 31.5 gram of coconut oil. The study results showed that the cases had a high meat intake, such as fish, eggs, beef, chicken, and cow's milk. The cases with a meat intake of more than 210 grams (upper quartile) had a higher risk of CHD in comparison with those with a meat intake below 108 grams (lower quartile). Meat intake, total protein, total cholesterol and total carbohydrate are predictors of CHD. ${ }^{(4)}$

The Indonesian Basic Health Research (Riskesdas) data indicate that the highest proportion of deaths from noncommunicable disease is caused by vascular disease, with a mortality rate of $20.5 \%$, comprising stroke $(15.4 \%)$ and ischemic heart disease $(5.1 \%) .{ }^{(5)}$ The Riskesdas results for the province of West Java also show that Bogor City has a prevalence of $12.1 \%$ for heart disease and $1.1 \%$ for stroke, which are both higher than the national prevalence of $8.2 \%$ fort heart disease and $0.9 \%$ for stroke. ${ }^{(6)}$ The purpose of the present study was to find any association between coconut milk intake and vascular disease in adults. In this study, vascular disease was limited to stroke and CHD.

\section{METHODS}

\section{Research design}

This study forms part of an umbrella cohort study on Risk Factors of Noncommunicable
Diseases (FRPTM). The study was of crosssectional design and was conducted between January 2011 and December 2012.

\section{Study subjects}

The respondents were 25-65 year old permanent residents of five villages (kelurahan) in Central Bogor subdistrict, Bogor City, consisting of Kelurahan Kebon Kalapa, Kelurahan Babakan Pasar, Kelurahan Babakan, Kelurahan Ciwaringin and Kelurahan Panaragan. The inclusion criteria were: 1). males and females, 2). respondents aged 40 years and older who had undergone electrocardiography, 3). respondents aged under 40 years with a history of heart disease or hypertension, or were active smokers, who had undergone electrocardiography, 4). respondents aged 25-65 years who had experienced specific stroke symptoms or sequelae and had undergone neurological examinations. The number of respondents who fulfilled the inclusion criteria was 4.187 persons.

\section{Data collection}

Data were collected by the WHO STEPS (7) method, comprising 1). interviews using a community health questionnaire (on sociodemographic characteristics, medical history of the respondents and their families, and risk factors) and nutritional questionnaire (on frequency and number of foods consumed), 2). measurement of blood pressure and physical or anthropometric assessment (weight, height, and abdominal circumference), 3). laboratory tests (fasting and 2-hour postprandial blood glucose levels, total cholesterol, HDL cholesterol, LDL cholesterol, and triglycerides), 4). electrocardiography and neurological examination. At the time of interview, the respondents were asked if they had ever experienced several symptoms of stroke. Those who admitted having had specific stroke symptoms or those who had stroke sequelae were asked to undergo neurologic examination. Respondents were diagnosed as having had a stroke if they had a positive history of stroke and had visible stroke sequelae. The diagnoses were 
confirmed by a neurologist. Respondents aged 40 years and over and respondents under 40 years of age who were active smokers or had hypertension or were known to have a history of heart disease, were asked to undergo electrocardiography. The recording was performed by means of an Elitech 300G electrocardiograph using the Minnesota code and the results were read by a specialist in cardiology and vascular diseases. ${ }^{\left({ }^{8}\right)}$ Respondents were diagnosed as having CHD if the EKG was abnormal, after confirmation of the diagnosis by the cardiologist. In the present study patients with vascular disease were defined as those who on medical examination were diagnosed as having stroke or CHD. Vascular disease was categorized as "yes" and "no" (not a vascular disease). Respondents were categorized as having a family history of vascular disease if one or more family members had been diagnosed as having vascular disease or had died from vascular disease. Family history of vascular disease was categorized as present and absent. Emotional stress was assessed using a self reporting questionnaire with 20 items (SRQ-20). ${ }^{(9)}$ Respondents were said to experience stress if they answered "Yes" to minimally 6 out of 20 questions in the instrument.

The age of the respondents was calculated from the difference in years between their last birthday and date of birth. Age was categorized into 4 groups, namely 25-34 years, 35-44 years, 45-54 years and 55-65 years. Gender of the respondents was divided into 2 categories, male and female. Smoking behavior was divided into 2 , i.e. smoker status and smoking frequency. Smoking status was divided into 3 categories, i.e. non-smoker, ex-smoker (daily and occasionally) and active smoker (daily and occasionally). Smoking frequency was also divided into 3 categories, i.e. never, occasional smoker (past and current) and daily smoker (past and current).

\section{Intake of high risk foods}

Coconut milk intake was determined by an enumerator from an academy of nutrition using dietary recall and food frequency questionnaire (FFQ). Coconut milk intake was divided into 4 categories, i.e. never, 1-2 times/week, 3-6 times/ week and $\geq 7$ times/week. In this analysis, coconut milk intake was divided into 2 categories, i.e. $\leq 2$ times/week (never and 1-2 times/week) and $\geq 3$ times/week (3-6 times/week and $\geq 7$ times/week). High risk food in this study comprised processed meat, eggs, milk, fried snacks, and frying oil. Data on consumption of high risk food was obtained by dietary recall and FFQ, and were then divided into into 2 categories, i.e. $\leq 2$ times/week (never and 1-2 times/week) and $\geq 3$ times/week (3-6 times/week and $\geq 7$ times/week), except for intake of frying oil. Intake of frying oil was categorized into 3, i.e. <2 times/day, 2-3 times/day and >3 times/day.

\section{Measurements}

Weight (W) was determined using AND digital scales. Respondents in light clothing were weighed barefoot in the standing position. Height $(\mathrm{H})$ was measured in the standing position using a Microtoise. Body mass index (BMI) was calculated from the weight $(\mathrm{W})$ and height $(\mathrm{H})$ using the formula:

$$
\mathrm{BMI}=\mathrm{W}(\mathrm{kg}) / \mathrm{H}(\mathrm{m})^{2}
$$

Based on the BMI classification for Asians according to the International Obesity Task Force (IOTF) ${ }^{(10)}$ was divided into 5 categories. These were: underweight (BMI <18.5), normal (18.522.9), overweight (23-24.9), obese I ( $\geq 25)$ and obese II $(\geq 30)$. In this advanced analysis, BMI was divided into 2 categories only, obese $(\geq 25)$ and non-obese $(<25)$.

Abdominal circumference was measured using non-elastic measuring tape by first determining the midpoint between the lower margin of the last palpable rib and the top of the iliac crest. From this midpoint the measuring tape was then placed horizontally around the abdomen and the result was recorded in $\mathrm{cm}$. The measurement was made at the end of a normal expiration. If the respondents had a prominent abdomen, the measurement was made over the most prominent portion. Central obesity was divided based on the cutoff point of abdominal circumference, differentiated by gender. 
Respondents were categorized as having central obesity if their abdominal circumference was $\geq 90$ $\mathrm{cm}$ for males and $\geq 80 \mathrm{~cm}$ for females. ${ }^{(10)}$

In the present study, blood pressure was measured twice at 3-minute intervals on the right arm by means of a digital sphygmomanometer. If the two systolic or diastolic blood pressure measurements differed by $\geq 10 \mathrm{~mm} / \mathrm{Hg}$, then a third measurement was made after a break of 10 minutes. Hypertension was categorized according to the 8th Joint National Committee (JNC) guideline for the year 2014. For systolic blood pressure, the categories were normal $(<120$ $\mathrm{mmHg}$ ), prehypertension $(120-139 \mathrm{mmHg}$ ), grade I hypertension (140-159 $\mathrm{mmHg})$, grade 2 hypertension $(\geq 160 \mathrm{mmHg})$. The diastolic blood pressure categories were normal $(<80 \mathrm{mmHg}$ ), prehypertension (80-89 $\mathrm{mmHg}$ ), grade I hypertension $(90-99 \mathrm{mmHg}$ ), and grade II hypertension $(\geq 100 \mathrm{mmHg}){ }^{(11)}$ Blood pressure measurements were performed by paramedics. Respondents were said to have hypertension if they had a previous diagnosis of hypertension or were currently taking antihypertensive drugs, or the current blood pressure measurements were above normal. In the present study blood pressure was categorized into 2, i.e. "yes" (hypertension) and "no".

\section{Laboratory investigations}

For determination of blood glucose and lipids, the respondents were asked to fast for 1214 hours from the previous night up to the time of taking blood samples in the morning. The respondents were only allowed to drink water. From the fasting respondents blood samples were drawn from the cubital vein, then the respondents were given a solution of 75 grams of glucose in $250 \mathrm{~mL}$ water. To respondents with known diabetes, a 300 calorie food supplement was given instead of the glucose solution. Subsequently, 2 hours after glucose loading, a second blood sample was drawn from the cubital vein. Evaluation of blood glucose status was carried out according to the guidelines of the National Institute of Diabetes and Digestive and Kidney Diseases. Fasting blood glucose (FBG) was divided into 3 categories, i.e. normal $\leq 99 \mathrm{mg} / \mathrm{dL}$, abnormal fasting blood glucose tolerance $100-125 \mathrm{mg} / \mathrm{dL}$, and high fasting blood glucose $\geq 126 \mathrm{mg} / \mathrm{dL}$. Two-hour postprandial blood glucose was divided into 3 categories, i.e. normal $\leq 139 \mathrm{mg} / \mathrm{dL}$, abnormal 2hour postprandial blood glucose tolerance 140$199 \mathrm{mg} / \mathrm{dL}$, and high 2-hour postprandial blood glucose $\geq 200 \mathrm{mg} / \mathrm{dL}$. Respondents were diagnosed as having diabetes mellitus if they had been diagnosed as having diabetes mellitus by health personnel or had fasting blood glucose levels of $\geq 126 \mathrm{mg} / \mathrm{dL}$ or 2-hour postprandial blood glucose levels of $\geq 200 \mathrm{mg} / \mathrm{dL}$. ${ }^{(12)}$

Determination of blood lipid levels comprised determination of total cholesterol, LDL cholesterol, HDL cholesterol, and triglycerides. Evaluation of blood lipid status was performed according to the guidelines of the National Cholesterol Education Program (NCEP 2004) as follows: total cholesterol level was divided into 2 categories, i.e. normal $(<200 \mathrm{mg} / \mathrm{dL})$ and high $(\geq 200 \mathrm{mg} / \mathrm{dL})$. Triglyceride level was divided into 2 categories, i.e. normal $(<150 \mathrm{mg} / \mathrm{dL})$ and high $(\geq 150 \mathrm{mg} / \mathrm{dL})$. LDL cholesterol level was divided into 2 categories, i.e. normal $<100 \mathrm{mg} / \mathrm{dL}$ ) and high $(\geq 100 \mathrm{mg} / \mathrm{dL})$. HDL cholesterol level was divided into 2 categories by gender, i.e. normal for females $>50 \mathrm{mg} / \mathrm{dL}$, and for males $>40 \mathrm{mg} /$ dL. Respondents were considered to have dyslipidemia if total cholesterol $\geq 200 \mathrm{mg} / \mathrm{dL}$, triglycerides $\geq 150 \mathrm{mg} / \mathrm{dL}$, LDL cholesterol $\geq 100$ $\mathrm{mg} / \mathrm{dL}$, and HDL cholesterol $\leq 50 \mathrm{mg} / \mathrm{dL}$ (females) or $\leq 40 \mathrm{mg} / \mathrm{dL}$ (males). ${ }^{(13)}$ Blood chemistry investigation was performed by Prodia Laboratory in Bogor City.

\section{Data analysis}

The data were analyzed by a bivariate test (chi square) to determine any association between coconut milk intake and a number of risk factors. Significantly associated variables were then analyzed by multiple logistic regression. The level of significance used was 0.05 .

\section{Ethical clearance}

The protocol of this study was accorded ethical clearance from the Ethics Commission of 
the Health Research and Development Board, Ministry of Health, Republic of Indonesia.

\section{RESULTS}

The proportion of vascular disease increased with advancing age, and was twice as high in female respondents than in males (Table 1). With regard to biological factors, the proportion of patients with vascular disease was higher in respondents who had central obesity, belonged to the obese category, or had hypertension, DM and dyslipidemia, as compared with respondents with normal biological factors $(\mathrm{p}=0.000)$. Similarly, the proportion of patients with vascular disease was higher in respondents with a family history of vascular disease in comparison with those without a family history $(\mathrm{p}=0.048)$. Therefore all these risk factors were included in the multivariate analysis (Table 1).

The results of bivariate analysis showed that with respect to smoker status, respondents who had more vascular diseases were smokers, either current smokers or ex-smokers $(30.5 \%)$, in comparison with those who were non-smokers. Regarding smoking frequency, respondents who had more vascular diseases were those who smoked, either daily or occasionally $(29.1 \%)$, in

Table 1. Patients with vascular disease by modifiable and nonmodifiable factors

\begin{tabular}{|c|c|c|c|c|c|}
\hline \multirow{3}{*}{ Risk factor } & \multicolumn{4}{|c|}{ Vascular disease } & \multirow{3}{*}{$\mathbf{p}$} \\
\hline & \multicolumn{2}{|c|}{ Y es } & \multicolumn{2}{|c|}{ No } & \\
\hline & $\mathbf{n}$ & $\%$ & $\mathbf{n}$ & $\%$ & \\
\hline \multicolumn{6}{|l|}{ Non-mod ifiab le } \\
\hline \multicolumn{6}{|l|}{ Age (years) } \\
\hline $25-34$ & 21 & 2.4 & 868 & 97.6 & 0.000 \\
\hline $35-44$ & 129 & 10.4 & 1107 & 89.6 & \\
\hline $45-54$ & 346 & 27.2 & 925 & 72.8 & \\
\hline $55-65$ & 250 & 31.6 & 541 & 68.4 & \\
\hline \multicolumn{6}{|l|}{ Genter } \\
\hline Male & 163 & 10.9 & 1337 & 89.1 & 0.000 \\
\hline Fem ale & 583 & 21.7 & 2104 & 78.3 & \\
\hline \multicolumn{6}{|l|}{ Fam ily history } \\
\hline Positive & 131 & 20.6 & 504 & 79.4 & 0.048 \\
\hline Negative & 615 & 17.3 & 2937 & 82.7 & \\
\hline \multicolumn{6}{|l|}{ Modifiable } \\
\hline \multicolumn{6}{|l|}{ Central obesity } \\
\hline Yes & 430 & 22.8 & 1456 & 77.2 & 0.000 \\
\hline No & 316 & 13.7 & 1985 & 86.3 & \\
\hline \multicolumn{6}{|l|}{ BMI } \\
\hline Obese & 411 & 21.9 & 1467 & 78.1 & 0.000 \\
\hline Non obese & 335 & 14.5 & 1974 & 85.5 & \\
\hline \multicolumn{6}{|l|}{ Hypertension } \\
\hline Yes & 430 & 30.0 & 1002 & 70.0 & 0.000 \\
\hline No & 316 & 11.5 & 2439 & 88.5 & \\
\hline \multicolumn{6}{|l|}{ Diabetes Mellitus } \\
\hline Yes & 123 & 30.5 & 280 & 69.5 & 0.000 \\
\hline No & 623 & 16.5 & 3161 & 83.5 & \\
\hline \multicolumn{6}{|l|}{ Dysipidem ia } \\
\hline Yes & 83 & 25.3 & 245 & 74.7 & 0.000 \\
\hline No & 663 & 17.2 & 3196 & 82.8 & \\
\hline
\end{tabular}


Table 2. Distribution of vascular disease patients by behavioral factor

\begin{tabular}{|c|c|c|c|c|c|}
\hline \multirow{3}{*}{ Behavio ral factor } & \multicolumn{4}{|c|}{ Vascular disea se } & \multirow{3}{*}{$\mathbf{p}$} \\
\hline & \multicolumn{2}{|c|}{ Yes } & \multicolumn{2}{|c|}{ No } & \\
\hline & $\mathbf{n}$ & $\%$ & $\mathbf{n}$ & $\%$ & \\
\hline \multicolumn{6}{|l|}{ Smoker status } \\
\hline Current smoker & 179 & 12.3 & 1279 & 87.7 & 0.000 \\
\hline Ex-smoker & 140 & 18.2 & 631 & 81.8 & \\
\hline Non smoker & 427 & 21.8 & 1531 & 78.2 & \\
\hline \multicolumn{6}{|l|}{ Stmokingfrequency } \\
\hline D aily & 175 & 13.2 & 1148 & 86.8 & 0.000 \\
\hline Occasionally & 144 & 15.9 & 762 & 84.1 & \\
\hline Never & 427 & 21.8 & 1531 & 78.2 & \\
\hline \multicolumn{6}{|l|}{ Emotional stres } \\
\hline Yes & 242 & 21.0 & 909 & 79.0 & 0.001 \\
\hline No & 502 & 16.6 & 2531 & 83.4 & \\
\hline \multicolumn{6}{|l|}{ Consumption of highrisk foods } \\
\hline \multicolumn{6}{|l|}{ Coconut milk } \\
\hline$\geq 3$ timesweek & 253 & 19.1 & 1071 & 80.9 & 0.140 \\
\hline$\leq 2$ timesweek & 493 & 17.2 & 2370 & 82.8 & \\
\hline \multicolumn{6}{|l|}{ Processed meat } \\
\hline$\geq 3$ tim es'week & 450 & 17.2 & 2159 & 82.8 & 0.227 \\
\hline$\leq 2$ tim es'week & 296 & 18.8 & 1282 & 81.2 & \\
\hline \multicolumn{6}{|l|}{$\mathrm{E}_{\mathrm{ggs}}$} \\
\hline$>3$ tim es'week & 405 & 17.3 & 1930 & 82.7 & 0.371 \\
\hline$<2$ timesweek & 341 & 18.4 & 1511 & 81.6 & \\
\hline \multicolumn{6}{|l|}{ Milk } \\
\hline$>3$ timesweek & 194 & 17.4 & 924 & 82.6 & 0.715 \\
\hline$<2$ tim es'week & 551 & 18.0 & 2517 & 82.0 & \\
\hline \multicolumn{6}{|l|}{ Fried snacks } \\
\hline$>3$ timesweek & 139 & 15.0 & 789 & 85.0 & 0.011 \\
\hline$<2$ times'week & 607 & 18.6 & 2652 & 81.4 & \\
\hline \multicolumn{6}{|l|}{ Intake of frying oil } \\
\hline$>3$ timesday & 349 & 17.8 & 1609 & 82.2 & 0.126 \\
\hline 2-3 timesiday & 229 & 19.4 & 954 & 80.6 & \\
\hline$<2$ times'day & 168 & 16.1 & 878 & 83.9 & \\
\hline
\end{tabular}

comparison with those who never smoked. The proportion of respondents with emotional disturbances had more vascular diseases in comparison with respondents without emotional disturbances ( $\mathrm{p}=0.001)$ (Table 2). According to frequency of consumption of high risk foods, all foods were included in the multivariate analysis, with the exception of eggs $(\mathrm{p}=0.371)$ and milk $(\mathrm{p}=0.715)$, since these foods did not show a significant association. The highest proportion of patients with vascular disease was found among respondents who consumed coconut milkcontaining foods $\geq 3$ times/week (19.1\%). However, the highest proportion of patients with vascular disease was also found among respondents who consumed prepared meat $(18.8 \%)$ and fried snacks $(18.6 \%) \leq 2$ times/week. The highest proportion of frying oil intake was 23 times/day (19.4\%).

According to the results of multivariate analysis (Table 3 ), coconut milk intake of $\geq 3$ times/week significantly increased the risk of vascular disease by 1.3 fold in comparison with coconut milk intake with a frequency of $\leq 2$ times/ week, after controlling for other risk factors i.e. age, gender, hypertension, diabetes and stress $(\mathrm{OR}=1.33 ; 95 \% \mathrm{CI}: 1.11-1.60 ; \mathrm{p}=0.002)$. However, the risk of coconut milk intake for vascular disease was lower than that of age, gender, hypertension, and diabetes mellitus. 
Table 3. Association of several risk factors and vascular disease

\begin{tabular}{|c|c|c|c|c|c|c|c|}
\hline \multirow{3}{*}{ Risk factor } & \multicolumn{4}{|c|}{ Vascular disease } & \multirow{3}{*}{$\begin{array}{l}\text { Adjusted } \\
\text { OR }\end{array}$} & \multirow{3}{*}{$95 \% \mathrm{CI}$} & \multirow{3}{*}{$\mathbf{p}$} \\
\hline & \multicolumn{2}{|c|}{ Yes } & \multicolumn{2}{|c|}{ No } & & & \\
\hline & n & $\%$ & n & $\%$ & & & \\
\hline \multicolumn{8}{|l|}{ Coc onut milk } \\
\hline$>3$ tim estweek & 253 & 19.1 & 1071 & 80,9 & 1.33 & $1.11-1.60$ & 0.002 \\
\hline$<2$ tim eshoek & 493 & 17.2 & 2370 & 82.8 & 1.00 & Reference & \\
\hline \multicolumn{8}{|l|}{ Age (years) } \\
\hline $55-65$ & 250 & 31.6 & 541 & 68.4 & 16.16 & $10.00-26.10$ & 0.000 \\
\hline $45-54$ & 346 & 27.2 & 925 & 72.8 & 13.37 & $8.39-21.33$ & 0.000 \\
\hline $35-44$ & 129 & 10.4 & 1107 & 89.6 & 4.53 & $2.80-7.35$ & 0.000 \\
\hline $25-34$ & 21 & 2.4 & 868 & 97.6 & 1.00 & Reference & \\
\hline \multicolumn{8}{|l|}{ Gender } \\
\hline Female & 583 & 21.7 & 2104 & 78.3 & 2.39 & $1.96-2.92$ & 0.000 \\
\hline Male & 163 & 10.9 & 1337 & 89.1 & 1.00 & Reference & \\
\hline \multicolumn{8}{|l|}{ Hypertens on } \\
\hline Yes & 430 & 30.0 & 1002 & 70.0 & 1.93 & $1.62-2.30$ & 0.000 \\
\hline No & 316 & 11.5 & 2439 & 88.5 & 1.00 & Reference & \\
\hline \multicolumn{8}{|l|}{ Diabetes Mellitus } \\
\hline Yes & 123 & 30.5 & 280 & 69.5 & 1.36 & $1.07-1.74$ & 0.014 \\
\hline No & 623 & 15 & 3161 & 83,5 & 1,00 & Reference & \\
\hline \multicolumn{8}{|l|}{ Stress } \\
\hline Yes & 242 & 21.0 & 909 & 79.0 & 1.31 & $1.09-1.58$ & 0.005 \\
\hline No & 502 & 16.6 & 2531 & 83.4 & 1.00 & Reference & \\
\hline
\end{tabular}

*Adjusted odds ratio controlled for variables

\section{DISCUSSION}

In this study it was found that frequent coconut milk intake ( $\geq 3$ times/week) increases the risk of vascular disease as compared with infrequent intake ( $\leq 2$ times/week). This signifies that coconut milk intake $\geq 3$ times/week is already predictive, i.e. increases the risk of suffering from vascular disease, after controlling for other risk factors, i.e. age, gender, hypertension, diabetes mellitus, and stress. Coconut milk intake $\leq 2$ times/ week may be said to be within safe consumption limits. However, the effect of coconut milk containing much saturated fatty acid on the risk of vascular disease is still low in comparison with the four other risk factors, i.e. age, gender, hypertension, and diabetes mellitus. One study showed similar results, where consumption of moderate quantities of coconut oil, as a part of routine diet, may not contribute to the risk for coronary artery disease, either directly by affecting the lipid profile or indirectly by aggravating oxidative stress. ${ }^{(14)}$ Saturated fatty acids are fatty acids without double bonds in their hydrocarbon chain, are stable, do not readily oxidize, and are not converted into trans fatty acids or other deleterious compounds. Coconuts and their products, such as coconut oil and coconut milk, contain much medium chain saturated fatty acids that are readily absorbable, digestible, and can be rapidly metabolized, therefore they are not found in the circulation, and cannot form vascular plaques (are not atherogenic). ${ }^{(15)}$ The effect of certain foods on CHD cannot be predicted merely on the basis of their saturated fatty acid content, since the saturated fatty acids themselves may have an effect on the heart and blood vessels. In addition, most sources of saturated fatty acids have contents that affect the risk of CHD. ${ }^{(16)}$

The study conducted by Yamagishi et al. ${ }^{(17)}$ found a protective effect of saturated fatty acid intake on total stroke [HR=0.77; 95\% CI: 0.650.93 ; trend $\mathrm{p}=0.002]$ and ischemic stroke [HR=0.84; 95\% CI: 0.67-1.06; trend $\mathrm{p}=0,08]$, but was predictive of myocardial infarction [HR=1,39; 95\% CI: 0,93-2,08; trend $p=0,046]$ although the latter effect was not significant. Similar findings results were revealed in a meta- 
analysis of prospective epidemiological studies conducted by Siri-Tarino et al. ${ }^{(18)}$ The investigators found no significant evidence to conclude that saturated fat intake was associated with increased risk of vascular disease, such as CHD, stroke and cardiovascular disease (CVD).

The study conducted by Ekanayaka et al. ${ }^{(19)}$ found that supplementation of coconut milk significantly reduced LDL cholesterol levels and increased HDL cholesterol levels. According to Silalahi and Nurbaya, ${ }^{(20)}$ coconut oil and coconut milk do not increase LDL cholesterol and are protective for CHD. This due to the role of HDL cholesterol in reversing cholesterol transport from the cell membrane to the liver, allowing the liver to remove excess cholesterol from peripheral tissues, thus protecting the organs from atherosclerosis. The results of the study of Griel and Etherton ${ }^{(21)}$ showed that increases in HDL cholesterol levels also significantly reduced the total cholesterol to HDL cholesterol ratio. A reduction of one unit in the total cholesterol to HDL cholesterol ratio signifies a reduction in the risk of myocardial infarction by $53 \%$. Therefore it may be stated that intake of saturated fatty acidcontaining coconut milk is not a risk factor of vascular disease.

In the advanced analysis of the baseline data of the Cohort Study on Risk Factors of Noncommunicable Diseases (FRPTM) there were several limitations. One of these is that in the data collection on smoking, ex-smokers were not asked the number of cigarettes that they had consumed as active smokers. Therefore the data on smoking were assigned to 2 variables i.e. smoking status and frequency. Smoking status was divided into 3 categories, i.e. non-smokers, ex-smokers (daily and occasional) and active smokers (daily and occasional). Smoking frequency was also divided into 3 categories, i.e. never smokers, occasional smokers (past and current) and daily smokers (past and current). Furthermore, among the participants in the FRPTM cohort study there were more females than males, thus influencing the results of the analysis. From the results of this study, the community is expected to take measures for preventing vascular disease as early as possible, particularly with respect to healthy life style, i.e. by performing physical activity (sports), refraining from smoking, and avoiding alcohol consumption. In addition, dietary intake should be of nutritional value and healthy, to avoid suffering from vascular disease. Measures for control of vascular disease should be focused on individuals (particularly female pre-elderly and elderly persons) with hypertension, diabetes mellitus, and stress. More studies should be conducted on consumption of coconut products, especially coconut milk, that are related to noncommunicable diseases such as stroke, $\mathrm{CHD}$, or diabetes mellitus, due to the high coconut milk consumption by the communities of various regions of Indonesia.

\section{CONCLUSIONS}

Frequent coconut milk intake ( $\geq 3$ times/ week) increases the risk of vascular disease, but the magnitude of the risk is still lower than that for other risk factors such as age, gender, hypertension, and diabetes mellitus.

\section{CONFLICT OF INTEREST}

The authors declare that there is no conflict of interest in this study and in the advanced analysis.

\section{ACKNOWLEDGEMENTS}

The research team hereby wish to express their utmost gratitude to dr. Eddy Darma and dr. Siti Robiah of the Bogor Health Service, dr. Lily, dr. Irma, dr. Atik, Ms Tri Yuliani, Ms Anisa, and Ms Yuli of all cooperating Puskesmas in the villages (kelurahan) of Kebon Kalapa, Ciwaringin, Panaragan, Babakan and Babakan Pasar. Thanks are also due to Ms Ida Paulina of Prodia Laboratory, Prof.DR.dr. Budi Setianto, Sp.JP and Prof.DR.dr. Bambang BS, Sp.JP of Harapan Kita Hospital, and dr. M. Kurniawan, Sp.S of Cipto Mangunkusumo National General 
Hospital for guidance and directions in this study. We also thank all health cadres of Kelurahan Kebon Kalapa, Ciwaringin, Panaragan, Babakan and Babakan Pasar, for their excellent cooperation in data collection, dr. Iwan Ariawan of FKM-UI for his guidance and directions in data analysis, so that the results can benefit all parties, particularly decision and policy makers, and all ST-FRPTM colleagues for their cooperation in conducting this study.

\section{REFERENCES}

1. Sulistyowati T. Efek perbedaan sumber dan struktur kimia asam lemak jenuh terhadap kesehatan. Buletin Penelitian Kesehatan 2010;38:43-51.

2. Pehowich DJ, Gomez AV, Barnes JA. Fatty acid composition and possible health effect of coconut constituents. West Indian Med J 2000;49:12833.

3. Ejike CECC, Nwankwo OO, Ijeh II. Consumption of coconut milk did not increase cardiovascular disease risk in mice. Int J Current Res 2010;6:63-4.

4. Lipoeto NI, Agus Z, Oenzil F, et al. Dietary intake and the risk of coronary heart disease among the coconut-consuming Minangkabau in West Sumatra, Indonesia. Asia Pac J Clin Nutr 2004;13:337-84.

5. Badan Penelitian dan Pengembangan Kesehatan. Riset kesehatan dasar Indonesia 2007 : laporan nasional. Jakarta: Badan Penelitian dan Pengembangan Kesehatan;2008.

6. Badan Penelitian dan Pengembangan Kesehatan. Riset kesehatan dasar Indonesia 2007: laporan Provinsi Jawa Barat. Jakarta: Badan Penelitian dan Pengembangan Kesehatan;2008.

7. World Health Organization. The WHO STEPwise approach to noncommunicable disease risk factor surveillance (STEPS). Geneva: World Health Organization;2014..

8. Prineas RJ, Crow RS, Zhu-Ming Z, editors. The Minnesota code manual of electrocardiographic findings. $2^{\text {nd }}$ ed. London: Springer;2010.

9. Scholte WF, Verduin F, van Lammeren A, et al. Psychometric properties and longitudinal validation of the self-reporting questionnaire (SRQ-20) in a Rwandan community setting: a validation study. BMC Medical Research Methodology 2011;11:116.
10. Razak F, Anand SS, Shannon H, et al. Defining obesity cutoff points in a multiethnic population. Circulation 2007;115:2111-8.

11. American Academy of Family Physicians. JNC 8 guidelines for the management of hypertension in adults. Am Fam Physician 2014;90:503-4.

12. The National Diabetes Information Clearinghouse. Diabetes overview. Bethesda, MD: The National Diabetes Information Clearinghouse;2008.

13. Lorenzo C, Williams K, Hunt KJ, et al. The National Cholesterol Education Program-Adult Treatment Panel III, International Diabetes Federation, and World Health Organization. Definitions of the metabolic syndrome as predictors of incident cardiovascular disease and diabetes. Diabetes Care 2007;30:8-13.

14. Sabitha P, Vaidyanathan K, Vasudevan DM, et al. Comparison of lipid profile and antioxidant enzymes among South Indian men consuming coconut oil and sunflower oil. Indian J Clin Biochem 2009;24:76-81.

15. Sulistyowati T. Efek asam lemak jenuh dan asam lemak tak jenuh "trans" terhadap kesehatan. Media Penelitian Pengembangan 2009;19 Suppl 2:S13-20.

16. Astrup A, Dyerberg J, Elwood P, et al. The role of reducing intakes of saturated fat in the prevention of cardiovascular disease: where does the evidence stand in 2010? Am J Clin Nutr 2011;93:684-8.

17. Yamagishi K, Iso H, Kokubo Y, et al. Dietary intake of saturated fatty acids and incident stroke and coronary heart disease in Japanese communities: the JPHC Study. Eur Heart J 2013; 34:1225-32.

18. Siri-Tarino PW, Sun Q, Hu FB, et al. Metaanalysis of prospective cohort studies evaluating the association of saturated fat with cardiovascular disease. Am J Clin Nutr 2010;91: 535-46.

19. Ekanayaka RAI, Ekanayaka NK, Perera B, et al. Impact of a traditional dietary supplement with coconut milk and soya milk on the lipid profile in normal free living subjects. J Nutr Metab 2013; Article ID 481068, 11 pages http:/ /dx.doi.org/10.1155/2013/481068 2013:1-11.

20. Silalahi J, Nurbaya S. Komposisi, distribusi, dan sifat aterogenik asam lemak dalam minyak kelapa dan kelapa sawit. J Indon Med Assoc 2011;61:453-7.

21. Griel AE, Kris-Etherton PM. Tree nuts and the lipid profile: a review of clinical studies. $\mathrm{Br} \mathbf{J}$ Nutr 2006;96 Suppl 2:S68-78. 